(Full Version)

\title{
But Mr. Clinton, Globalization has a Human Face
}

By

\section{Jagdish Bhagwati}

Jagdish Bhagwati is the Arthur Lehman Professor of Economics at Columbia University. He is the author of the best-selling Protectionism (1988) and his writings on public policy in leading newspapers and magazines have just been published in A Stream of Windows: Unsettling Reflections on Trade, Immigration and Democracy, both from MIT Press. An abbreviated version appeared in The Financial Times, August 17, 1999. 
President Clinton will play the host at the November Ministerial Meeting of the WTO in Seattle that is expected to launch the Millennium Round of multilateral trade negotiations. However, unlike his role model President John Kennedy whose name graces the sixth such Round, he has already missed the bus. It could have been his, the Clinton, Round for the asking if only he had responded enthusiastically and early to the cascading calls by many of us to do so.

But then, it may be just as well. For, it would have been odd, perhaps even a travesty, to name the next Round, designed to free trade further and to extend globalization, for a President who reportedly embraced, at the University of Chicago recently, the stereotypical critique that "globalization needs a human face".

Doubtless, that is what he hears from his pollsters who report such complaints from their "focus groups". And it is also what he surely hears from his and Vice President Gore's constituencies: the fearful labour unions and the militant non-governmental organizations (NGOs) that are not merely oblivious of the benefits of, but are hugely hostile to, foreign trade and investment.

But, in saying that globalization needs a human face, Mr. Clinton concedes that it lacks one! So, he surrenders before the battle is joined, even though he is on higher ground. Indeed, globalization has a human face. Oh sure, it needs cosmetic surgery on one cheek and a trinket in an ear: even the most glorious face can be prettified. But the central reality is that the glow in the face that makes it human, rather than a mere mask on the wall, comes from the fact that it is joined to a human body that takes sustenance from a set of beneficial policies that definitely include globalization rather than national isolation.

Indeed, one could vigorously challenge virtually every charge that has recently been leveled at the freeing of trade and direct foreign investment. But take just the most common such 
misconceptions: that trade and foreign investment produce poor in the rich countries; that they bypass, even worsen, poverty in the poor countries; that the multinationals, major players in the world economy today, exploit foreign workers; and that they also harm women at work. How simplistic, even contrary to the facts, all this is.

1. Starting in the 1980s when the real wages of US workers declined, interrupting the robust upward trend in the postwar years of prosperity, the unions in the rich countries have feared that the culprit must be globalization in shape of trade with poor countries and the outflow of direct foreign investment to them. The less unsophisticated among the unions therefore support free trade only among "like-wage" countries: they were relatively quiet in the US when the preferential Free Trade Agreement was with Canada but went ballistic when it was with Mexico.

The majority, however, have unabashedly asked for protection or opposed new trade liberalization with the poor countries. Alternatively, many have sought to increase the cost of production of their rivals there by asking for "level playing fields" through raising of the labour and environmental burdens there to levels similar to their own (in the absence of which they allege, without economic logic, that "social dumping" occurs). Of course, the former is classic import protectionism or "isolationism"; the latter is a form of "export protectionism", much like Voluntary Export Restraints, or what I have called "intrusionism” which is equally aimed at restraining free trade. Remember: if a beast is charging at you, you can either stop it by seizing its horns or break its charge by reaching out behind it and catching it by its tail.

But the fear of globalization that prompts this protectionist politics, building on the notion that Marx who unsuccessfully predicted the immiseration of the proletariat in the $19^{\text {th }}$ century is striking again with the aid of globalization, is itself unfounded. A principal element in 
the anti-globalization case is the assumption that the average (relative) prices of labour-intensive goods have steadily fallen, causing the real wages of the workers to fall: the celebrated StolperSamuelson argument of trade economists. But, the facts show that the opposite occurred: the argument cannot even get off the ground!

This sounds counter-intuitive since one is inclined to say that, as increasing numbers of countries among the poor ones have exported more over the years, the total supplies must have vastly increased and the prices of labour-intensive goods must have fallen drastically in world trade. The fact of the matter, however, is that the poor countries that have become richer, especially the Four Tigers at the outset and then the ASEAN countries, have gone from labourintensive exports to capital-intensive exports. Hence, the "net" exports of labour-intensive exports from the poor nations have not added up immensely; they have not been coming at us blockbuster style. Thus, Ross Garnaut of Australian National University has calculated how Japan withdrew from such exports in the 1970s, largely offsetting the rising labour-intensive exports of the Four Tigers, whereas the latter yielded to and fully accommodated the entry of China in the 1980s through mid-1990s. To put it another way, even though trade liberalization will tend to increase labour-intensive exports from the poor countries, rapid capital accumulation and technical change in capital-intensive industries will offset this and tend to raise, not lower, world prices of labour-intensive goods. No surprises there, except for the unions. Indeed, the surprise, if you take this argument to its logical conclusion, is that trade with the poor countries may have even been a beneficial influence on the real wages of workers in the rich countries, moderating instead of accentuating, the fall in real wages induced really by technical change that reduces demand for unskilled labour. 
Nor should we be browbeaten by the frequent contention that direct foreign investment has undercut the wellbeing of our workers. Aside from anything else, the argument focuses only on outbound flows, forgetting the inward flows. In a BBC debate on globalization sometime ago, I was treated to a clip that had the French mayor of the town that lost Hoover to Britain raging against multinationals; I could not help remarking that there had been no complaints when Hoover, a US firm, had come to his town in the first place. In the 1980s, when real wages were under greatest pressure, the US got almost as much investment as it made abroad. A telling example is provided by the Wall Street Journal reporters, Bob Davis and David Wessel, in their recent book, Prosperity, where they recall how Interstate 85, going through Piedmont Mountains in North Carolina, a traditional textile stretch of country, has now been nicknamed the Autobahn. The textiles lost abroad have been replaced by the influx of nearly 250 foreign firms, several German such as BMW and Hoechst. The workers are doing hugely better than when they were stuck with employment in textiles.

2. But does globalization work in the poor countries? True, policymakers have shifted from their postwar fears of integration into the global economy, and now see it as an opportunity rather than as a threat. President Cardoso of Brazil, a renowned sociologist who sounded the alarm with his dependencia thesis, is now at the forefront of efforts at globalization in Latin America. But the fears that have now, in an ironic reversal, shifted to the rich countries, have tended to be embraced by the NGOs and the unreconstructed left in the poor countries. Liberal reforms that necessitate opening the economies to more trade and direct investment are decried as beneficial only to the rich and actually harmful to the poor.

But here again, the reality is different. Autarkic policies, as practiced by India 
for over three decades, produced abysmal growth rates, handicapping the creation of jobs that would have pulled the poor into gainful employment. Both India and China, when they have experienced rapid growth, have managed to dent poverty in a sustainable fashion; and that rapid growth has been associated with a policy framework that has, in varying degrees, included globalization.

Rapid growth also generates, at given tax rates, the tax revenues that must be found if more schools are to be built, if healthcare is to be extended to the villages, if clean water is to be provided, and much else done for the poor. Without these revenues, liberal talk comes cheap; and it costs the poor dear when intellectuals who properly decry "abysmal poverty" improperly oppose globalization and liberal economic reforms whose absence only accentuates poverty. Indeed, even phenomena such as the continuing high rates of illiteracy in India where often parents do not send children to schools even when available, can be traced back to low growth: poor parents will not find it attractive to forego children's incomes when the prospect of finding jobs for them after schooling are dismal with poor growth of the economy.

3. Equally at variance with facts is the frequent charge that multinationals "exploit" foreign workers. The growing "living wage" movement on US campuses by students who typically denounce multinationals ignores two facts. Few workers are going to work, except under duress or in the gulag, for a "dying wage". Also, as it happens, the economists working on multinationals typically confront the phenomenon known as the "wage premium", i.e. multinationals usually pay more than the going wage, thus treating the workers better than their apparent opportunity cost. In fact, in my experience, it is the aspiration of both skilled and unskilled workers in the poor countries to get into multinationals. 
In my view, therefore, the condemnation of multinationals which earn profits for themselves and also bring economic benefits to both their employees, and certainly to their host countries, is entirely misplaced. Media reports also reveal that much of it in the US today is due to the labour unions, which oppose the outward flow of investments by multinationals and are therefore advancing their agendas through an energetic and well-financed recruitment of young activists.

Thus, John Sweeney, President of AFL-CIO, has poured “more than \$3 million into internships and outreach programs meant to interest students in careers as union activists" (Time, April 12, 1998). Many of these students have become anti-multinational activists on campuses across the US, and their proximity to the unions is manifest from the fact that they typically object to multinationals using sweatshops (often mistakenly confused with firms and factories paying low wages that naturally reflect the fact that these countries are poor and have low wages) in Guatemala while ignoring the many sweatshops (properly defined as violative of safety standards, minimum wage laws, legislated working conditions etc.) within the US itself. I once offered a couple of such students, who were sitting at a table on College Walk on Columbia campus and waylaid me with complaints about our corporations exploiting labour in sweatshops abroad, to use my Metrocard subway pass to go down to the garment district where there were many sweatshops indeed and to do something about them forthwith! Evidently unaware that we had the real sweatshops right here, they had been snookered into agitating instead against our investment abroad.

4. While, again, globalization is typically charged with hurting women --- as when multinationals, for example, are accused of exploiting female labour in the Export Processing Zones ---, the opposite may in fact be true. Thus, economists Sandra Black and Elizabeth 
Brainerd have argued recently that globalization has helped reduce the Gender Wage Gap in the US. Drawing on Gary Becker's idea that increased competition means that a firm would find it increasingly difficult to indulge its "taste for discrimination" such as hiring equally productive men at higher wages and yet survive, they show that increased import competition in the shape of increasing import shares in industries during 1977-1994 is associated with greater reduction in the men-women wage gap.

And, as for women's employment in the poor countries, surely the correct take on it is that it is the protectionist policies in the rich countries in industries such as textiles and garments that help to reduce the demand for female labour in the poor countries and is thus a contributory factor in keeping them poor. More important, without the benefit of suitable employment and income that alone can give them the economic independence, even women's human rights cannot be advanced meaningfully. For, it is easy enough to pass socially progressive legislation and yet accomplish little: you may legislate against men beating up their wives but, if the battered wife cannot walk away and support herself with a job, the legislation's potency is unlikely to be compelling.

None of this is to deny that we must have today what I call "Appropriate Governance", both domestic and international, to sustain and manage the world economy and the world polity. But we are bound to get its design all wrong if our political leadership lazily buys into the uninformed fears and the raging passions that drive the anti-globalization groups today. 
